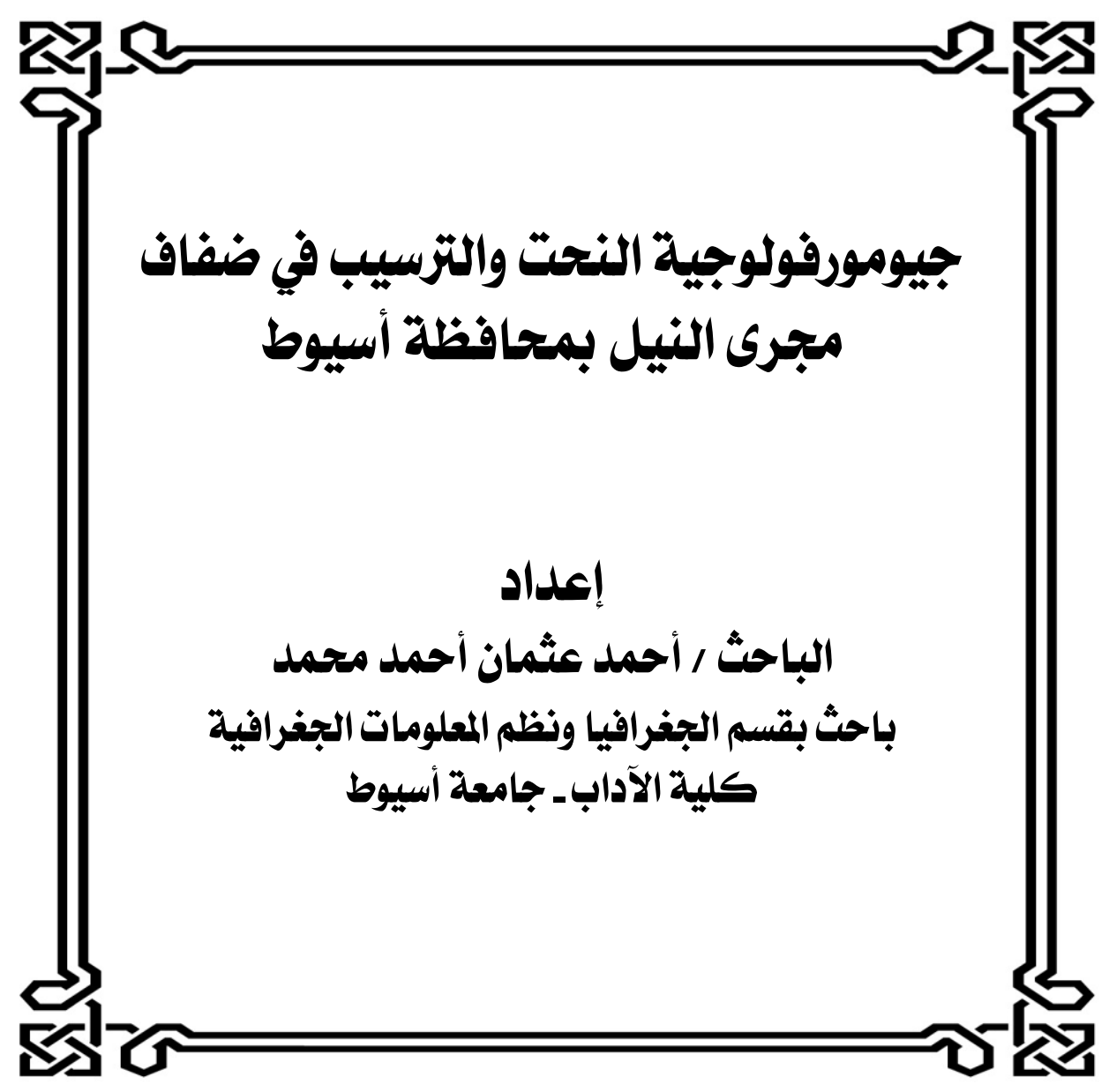


جيومونوبوجية النحت والترسيبل في ضفاف مجرى النيل

أحمل عثان أحسد محعد

\section{بسحا:مطة أسيرط}

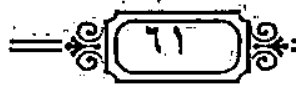

\section{: المقدمة}

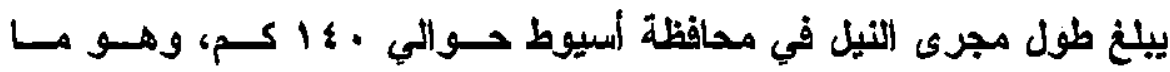
يمثل r\% من إجمالمي طول نهر النيل من منبعسه متــى مصـسبه، ويمنـل حـوالي \% من طول نهر النيل في مصر منذ دخوله عنــد أســوان حتــى مصــبه، بينمــا

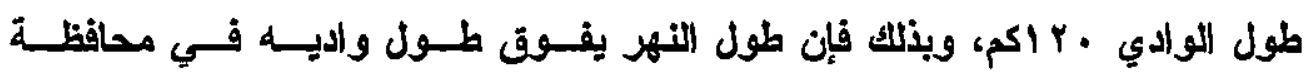

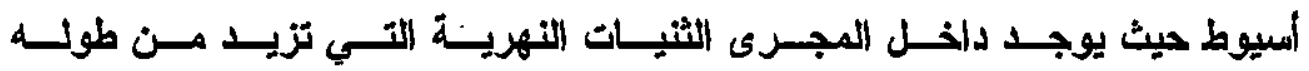

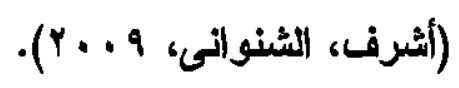

وتهدف دراســة جيومورفولوجيسة النحست والترسسيب لمجـري وضسفاف

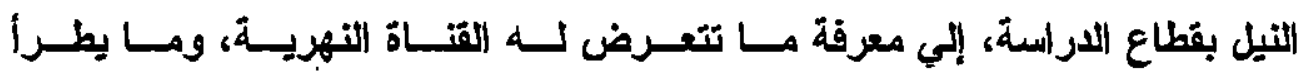

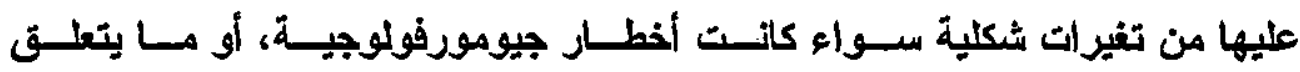

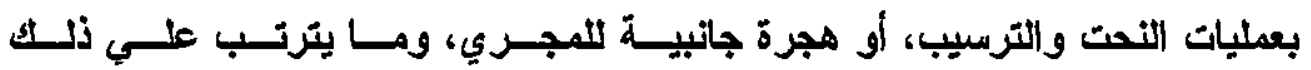

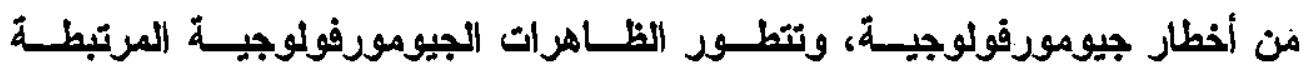

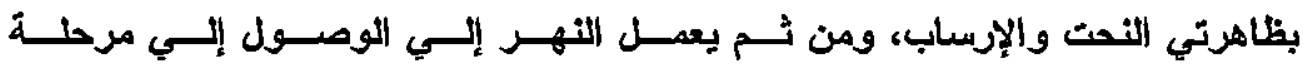

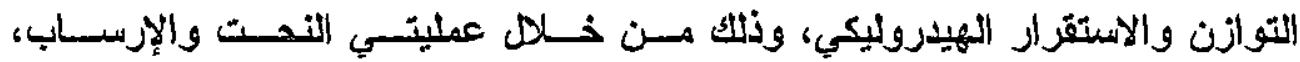
لذلك سيتم دراسة الظاهرات الجيومورفولوجية المرتبطة بضفاف النهر. 3

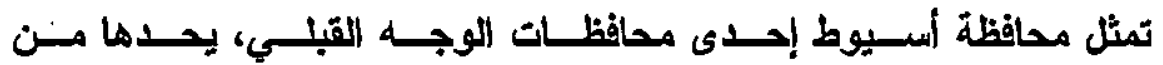

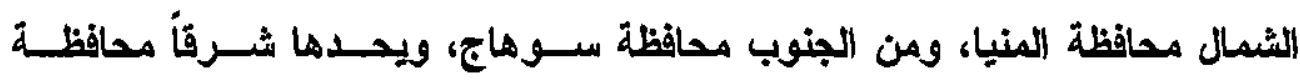

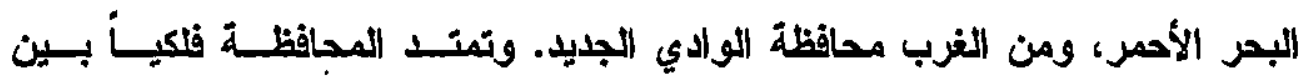


جيومونشولرجية النحت والترسيبي في ضفاف مجرى النيل

أحمل مثثان أحعل محصد

\section{بساهظة أسيوط}

=4r.

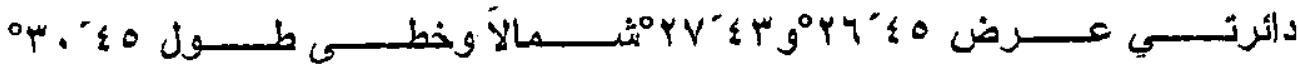

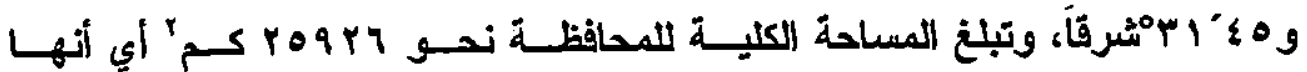

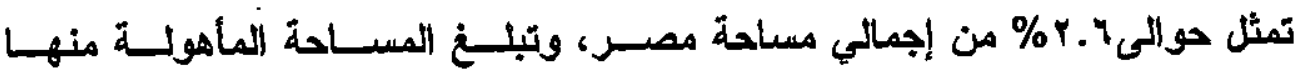

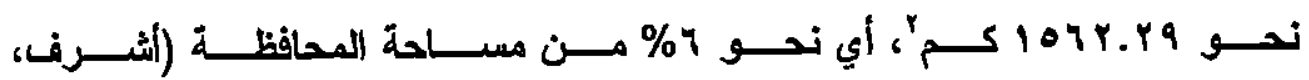

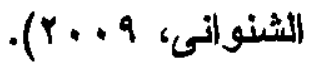

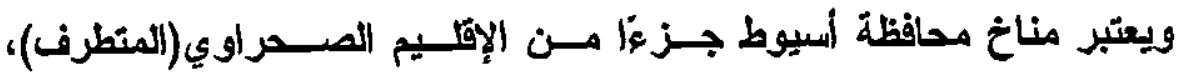

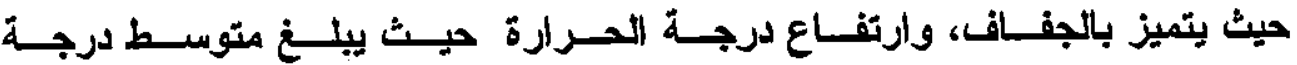

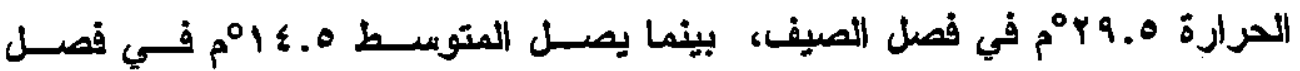

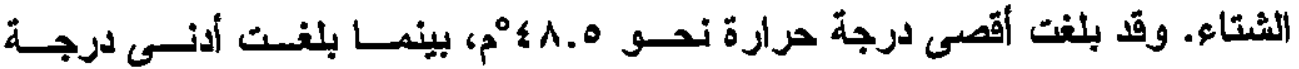

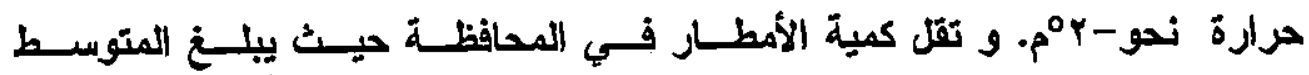

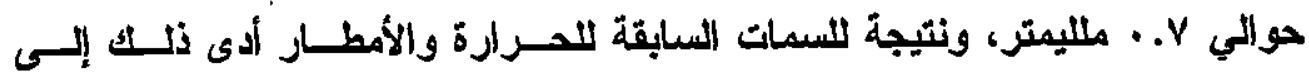

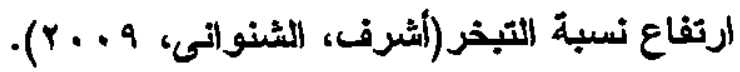

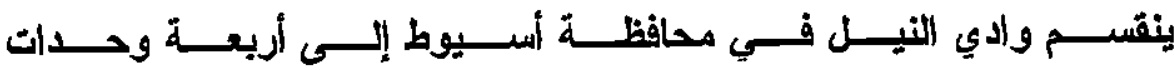

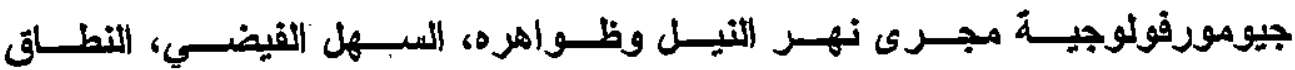

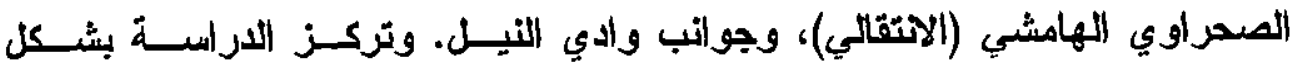

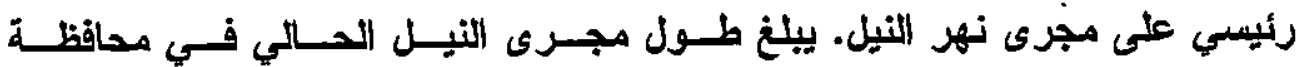

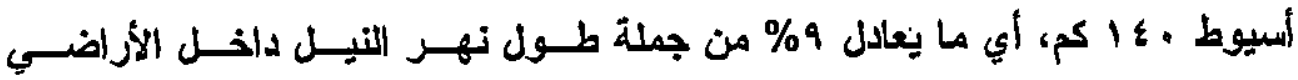

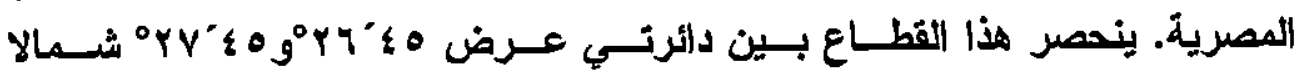

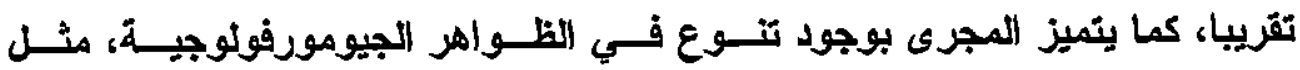

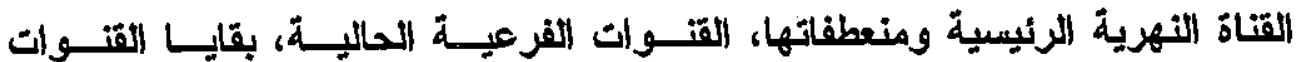

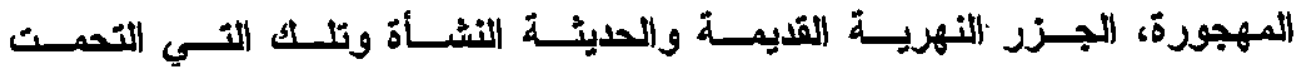


جيوموشولوجيح النحت والترسيب في فثاف مجرى النيل

أحسل عثمان أحمل محعل

\section{بمحاهظة أسيوط}

$=\frac{9}{75}$

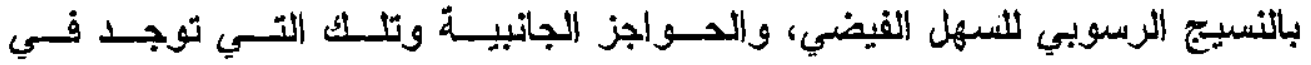
وسط المجرى.

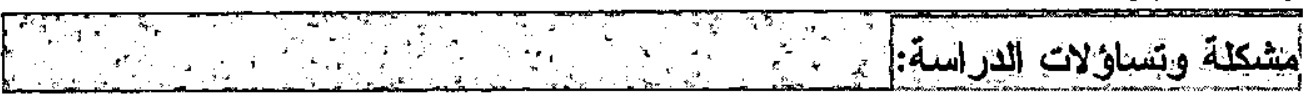

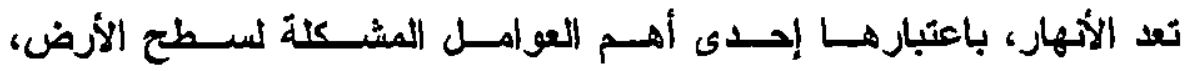
ذات ديناميكية واضحة تتباين مــا بـين الإحست والترسـيب، وتتثـير اللاراســات

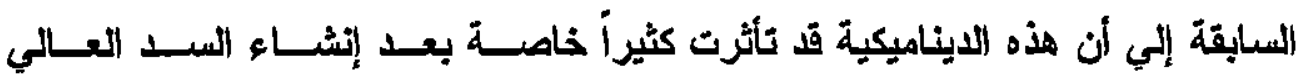

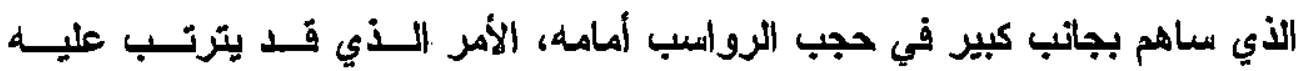
تغير في خصــائص التهــر الطبيعيـة مسن حيـث حجـم التصــريف وخصــائص

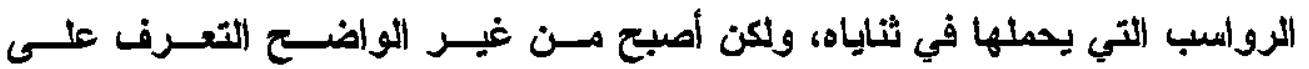

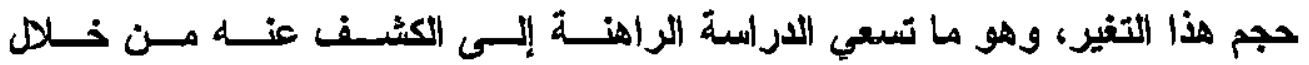
الإجابة علي التساؤلات التالية:

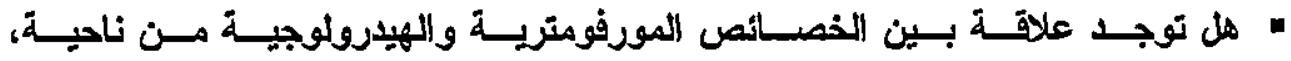

وعمليات النحت والتزبسب في مبري التيل بأسيوط من ناحية أخرى؟ • هل تؤثر الخصائص الميكانيكية والمعلنبــة للضـفاف والجـزر فــي عمليـات النحست

والترسيب؟

“ ما هي العوامل المسئولة عن تخيرات مجري نهر النيل؟ ״ ما هي معلات النحت والترسبيب بمجرى النهر في أسيوط؟

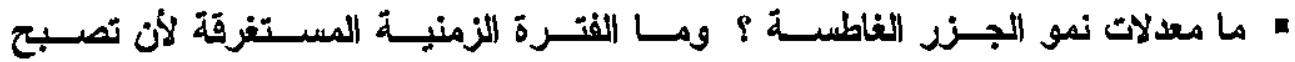
جزر مكشوفةٌ؟ 
جيومورفولمجيح النحت والترسيب لي ضناف مجرى النيل

أحسل عثمان أحمد محعد

\section{بعافظةل أسيرط}

$=\sqrt{6} \mathrm{~s}$

• ما طبيعة المشكلات المرتبطة بالنحت والتربيب بمجري نهر النيل ؟

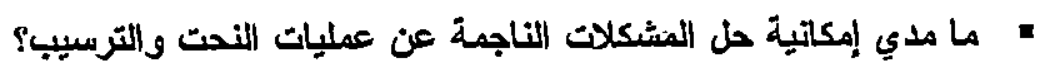

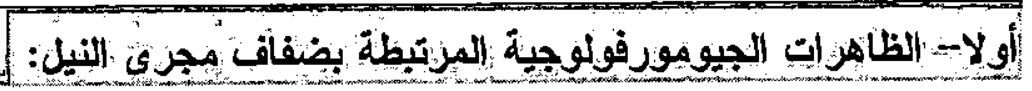

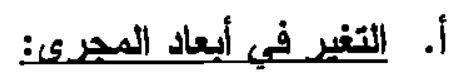
1- المقاطع العرضية.

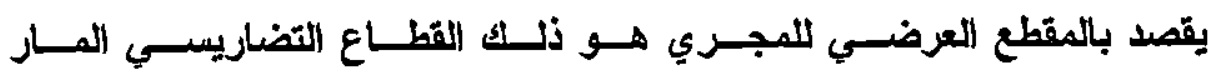

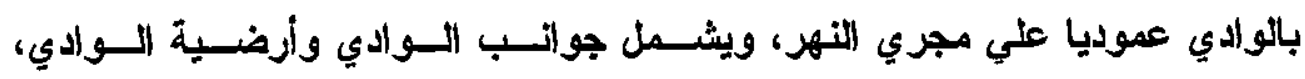

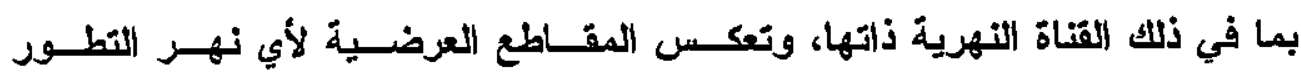

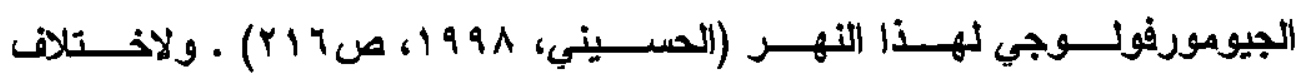

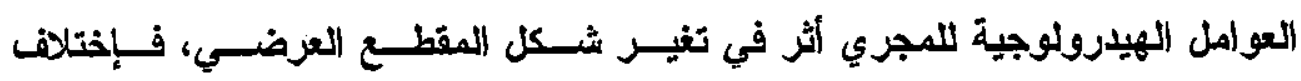

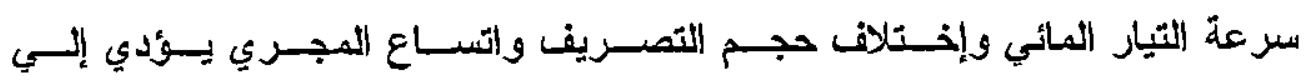

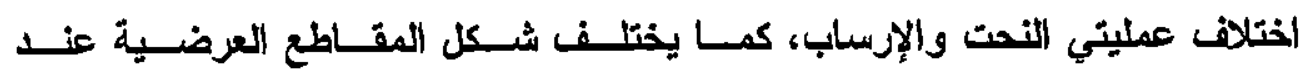

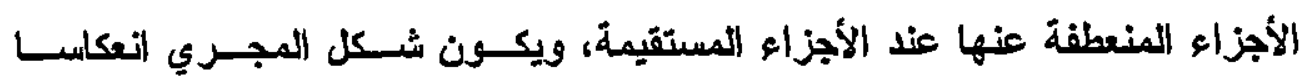

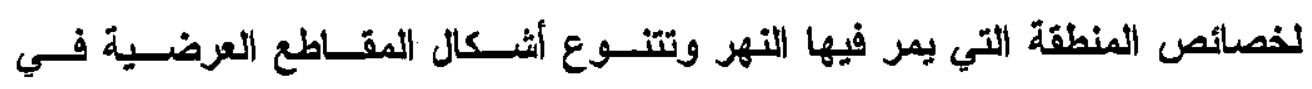

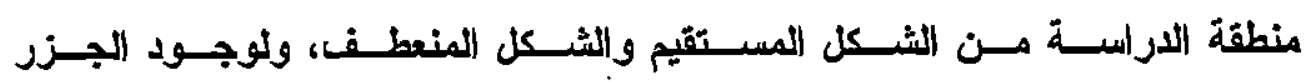

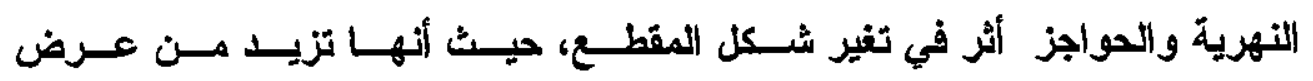


جيوسوسمالمجية النحت والترسيب في ضفاف مجرى النيل

أحسد عثمان أحسل مصحس.

\section{بمحافظلة أسيرط}

- 70 .

المجري، حتى إذا ما إلتحمت بإحـدى ضــفتي المجـري يقــل العــرض، ويالتــالي إختلاف عرض المجري حسب العملية الجيومورفولوجية السائدة . بينما يتوقف ثبات الضفاف على عدة عوامل مثل ارتفاع واتحدار الضفة، ومدى تماسك روانسب التربة ونوعها؛ ومستوى سطح المياه التي تؤثر في مختلف العمليات النهرية .وتمثل عملية التهدل فقد من جوانب الضفاف والجزر لصايح مياه النهر وأحيانا يحدث ذلك في شكل انزلاق راسي لطبقات بأكملها داخل مياه النهر Mostafa) et al, 1998, P.94) بمؤثرين مختلفين · يتمثئ الأول في زيادة عمق القطاع المعرضي رأسيا بسبب الفعل التحاتى للمياه الصافية التي تنطلق من خلف السد ـ ويمرور الزمن وبتقدم عمليات النحت الراسي للقاع فإن شكل المقطع العرضي يتغير من صورة الآساع الضحل إلى الثكل الضيق العميق ـ آما الثاني فيتمثل في عملية النحت الجانبي وتقويض الضفاف من • حيث كان لبناء السد العالم دورا في اتساع القناة النهرية على حساب الانهيار

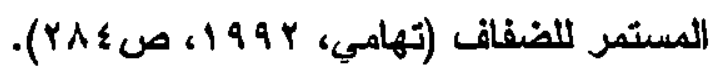

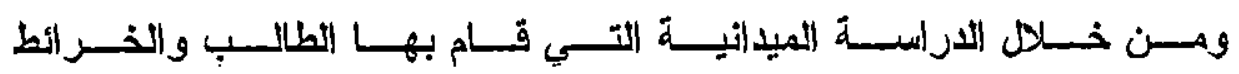

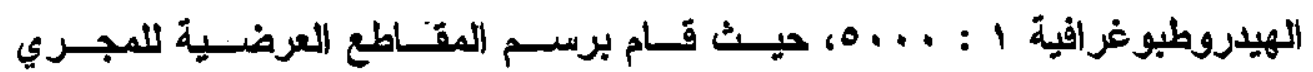

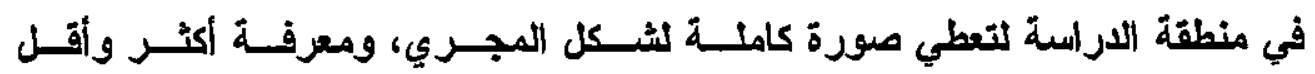

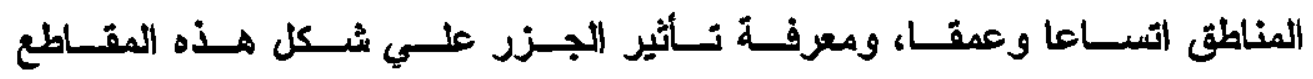

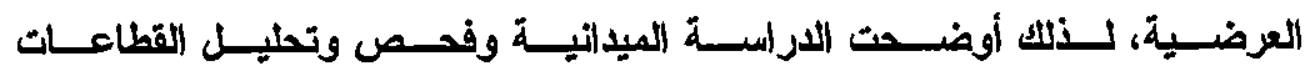
العرضية المجرى التيل في منطقة الار اسة ما يلي: 
جيومورفولمجية النحت واتترسيب في فضاف مجرى النيل

احمل عثمان أحعد مسحل

\section{بمحالنظة أسيوط}

=

74

อุ

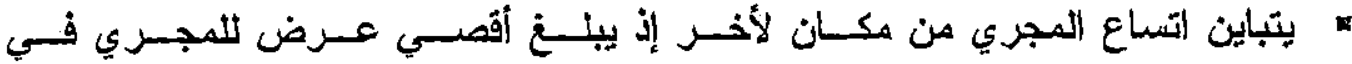

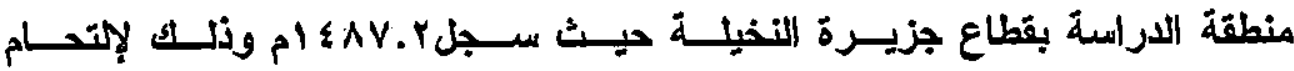

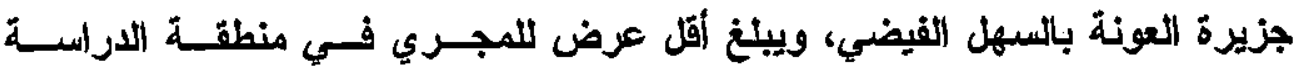

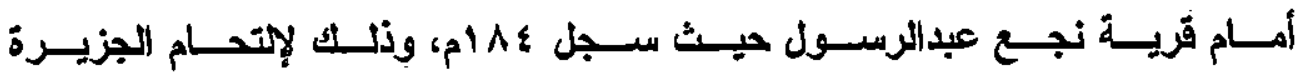
المواجهة للقرية بالضفة المغربية.

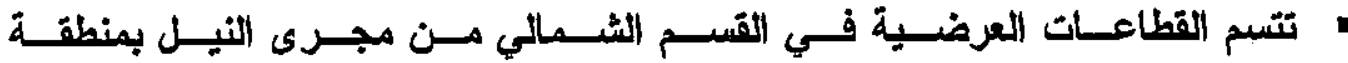

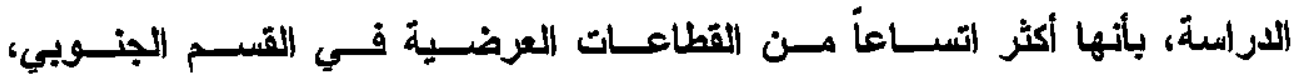
ويرجع ذلاك إلى عاملين، الأول ويتمثل فـي انخفــاض تصــرفات الميـاه الــواردة بعد بناء السد العالي، وفكة سرعة المياه في الأجــزاء الثــــالية، العامــل الأثـاني، ويتمثل في اعتراض قناطر أســيوط لتيــار المـــاء البطـــئ الـــوارد مــن الجنــوب،

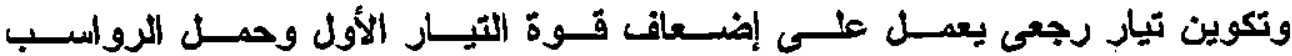

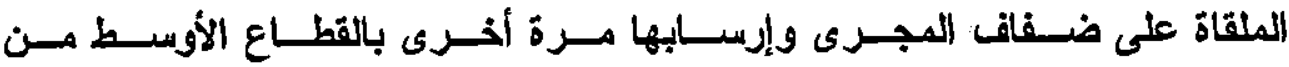
- المجري

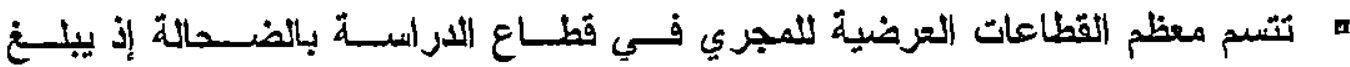

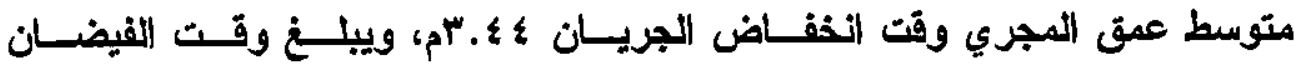

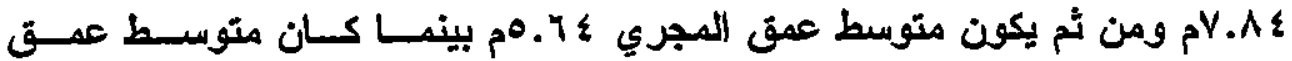

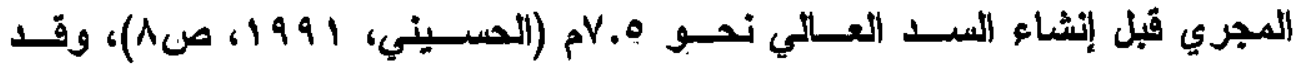

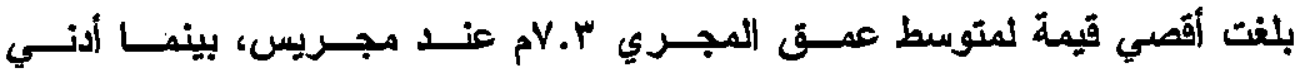
قيمة لمتوسط عمق المجري قد بلغت IV.Y. 


\section{بساهنظة أسيوط}

$=8$

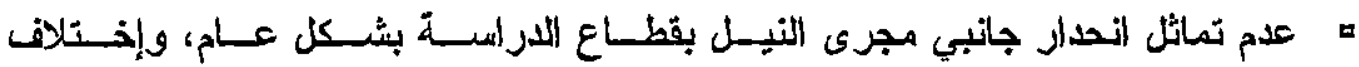

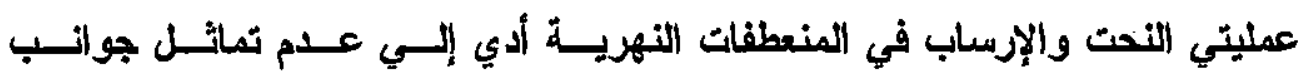

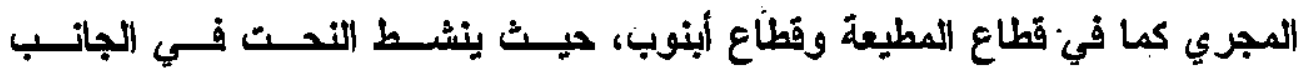
المقعر ويزيد الإرساب في الجانب المحدب . “ علم انتظام انحدارات قاع المجري، والسبب في ذلــك يرجــع إلــى وجسـود الجــزر

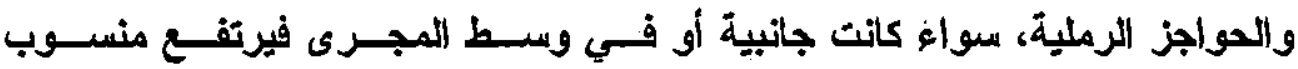
قاع المجري، حيث أن الجزر والحواجز من شـأنها أن تـؤدى إلـــى تبــاين شـكل قاع المجرى (Brooks, 1994, p.56). = إختلاف عمليتي النحت والإرساب في المنعطفـات النهريـــة أدي إلــي عـدم تماثـلـل جوانب المجري، حيث ينشط النحت فـي الجانسب المقعـر للمجـري، بينمــا يستم

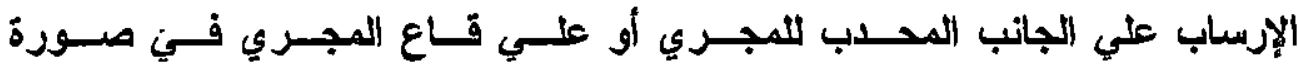

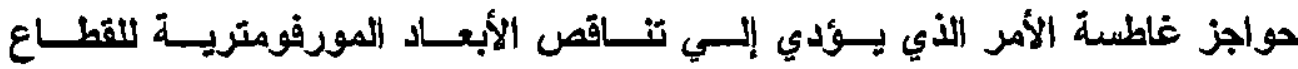
العرضي ومن ثُم انخفاض قيمة نصف القطر الهيدرولمجي. بongitudinal Profile بالقطاع الطولمي

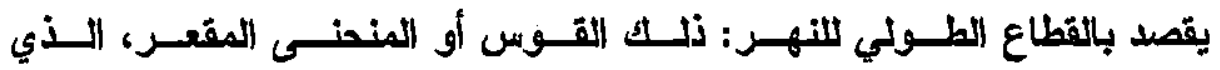

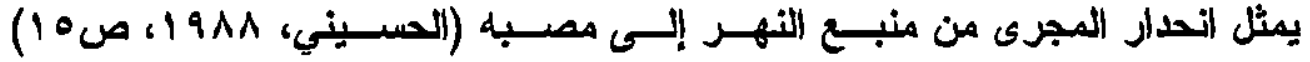

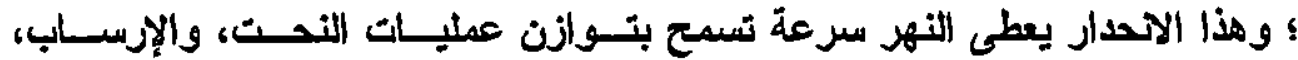

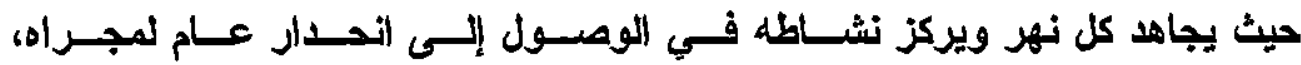
بحيث يكفى هذا الاتحدار لإعطاء تيـار التهــر ســرعة تســمح بتـوازن عميـات 
جيوموفولمجية النحت والترسيب في ضفاف مجرى النيل

أحسل مثمان أحسد مجعد

\section{بعالظة أسيوط}

= 7 \%

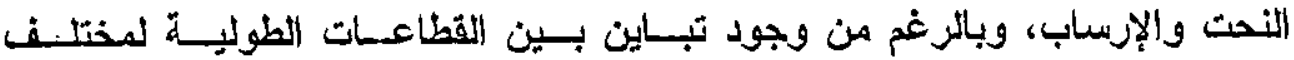

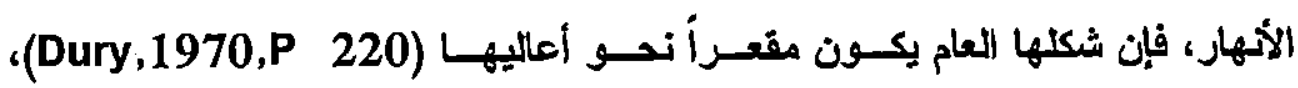

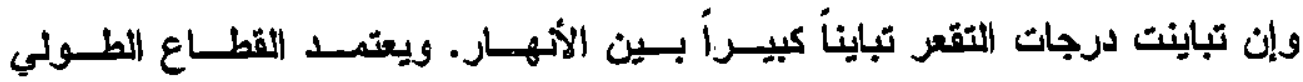

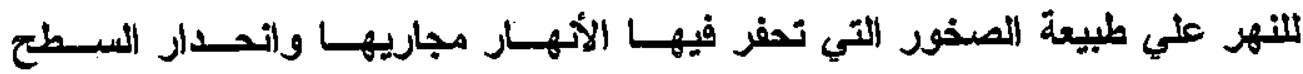

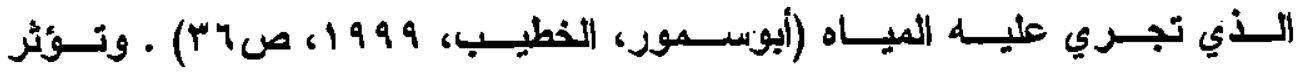

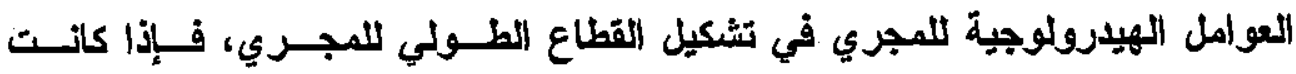

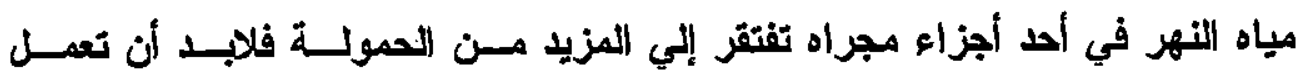

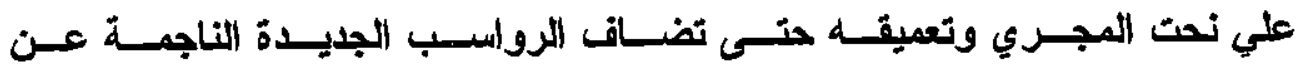

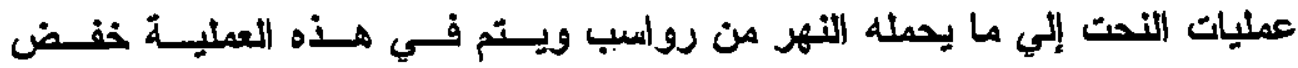

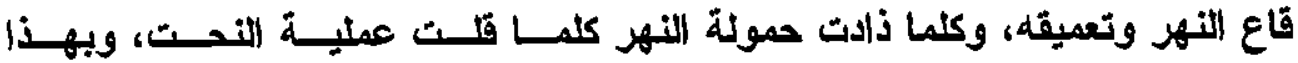

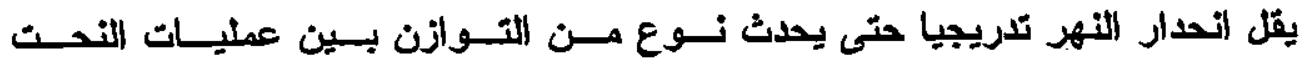

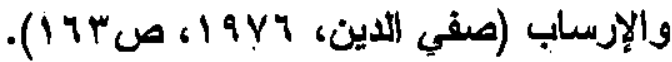

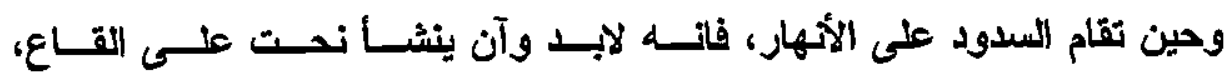

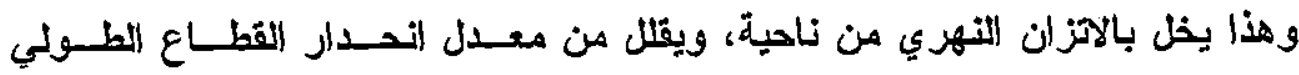

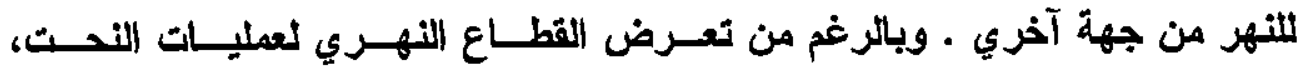
فإن شُكل القاع لا يتغير، وذلك لان النحت يكـــن موازيـــا للتــاع الآصــلى للتهــر

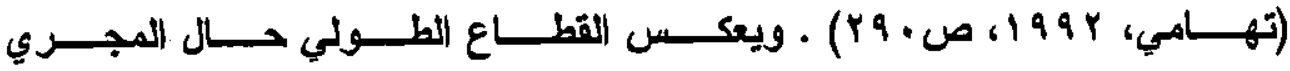
وخصائصه الهيدرولوجية من نظــام التصــريف المــائي وباتــالي ســرعة التيـار

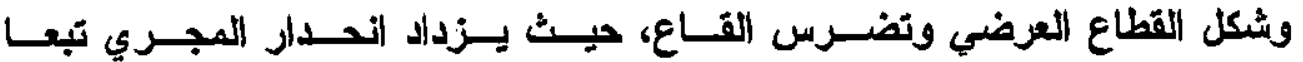


جيوموافولوجية النحت والترسيب في ثفاف سجرى الثيل

أحعل عثمان أحسل محتعل

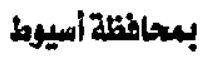

$=\frac{9}{99}$

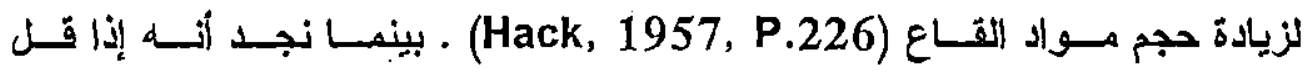

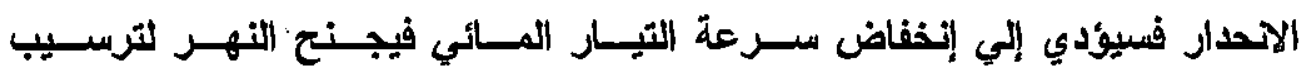
حمولته في شكل حواجز وجزر نهرية، كمــا أن مــدي تضـــس وخئسـونة القــاع يوضحان سيادة أي من عمليتي النحت والإرساب في قاع المجزي.

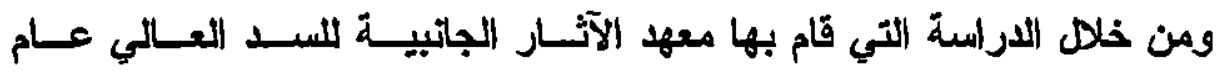

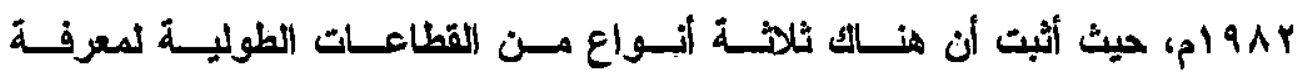
أنحدار المجري والقاع هي:

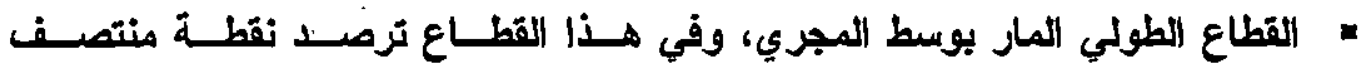
المجري، وهذا الاتطاع يفيد في حالة المجاري المستقيمة أكثر منها (المنعطفة.

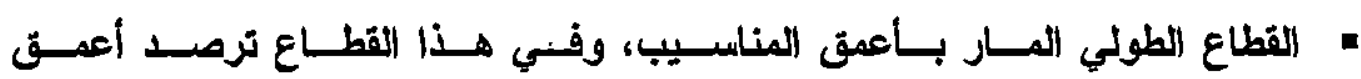

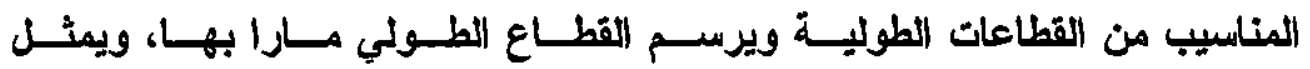
اللقطاع الطولي الناتج أقصي انحار علي قاع المجري.

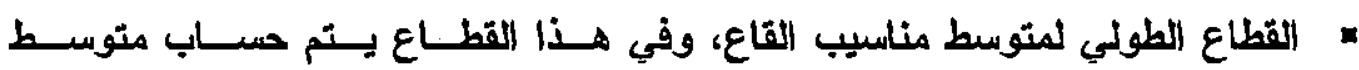
مناسيب القاع في نقاط معلومة، وهذه الطريقة تعبلر عن الاتحدار المثوسط.

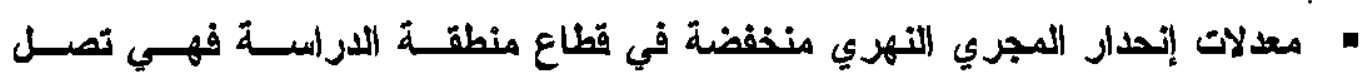

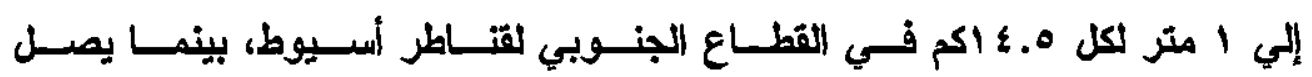

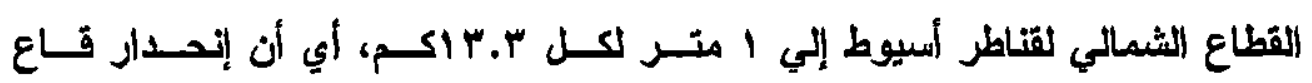

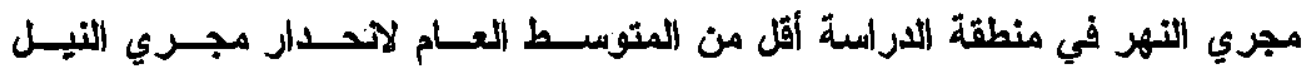

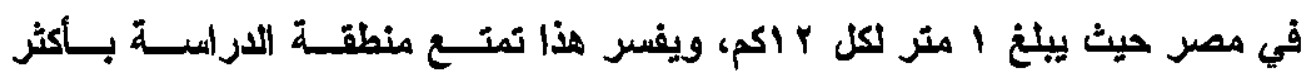


جيومسوفوبوجية النحت والترسيب في ضفاف مجرى النيل

أحمد عثمان أحمد محعد

\section{بعحانظة أسيوط}

$=\frac{\mathrm{C} \cdot \mathrm{C}}{\mathrm{o}}$

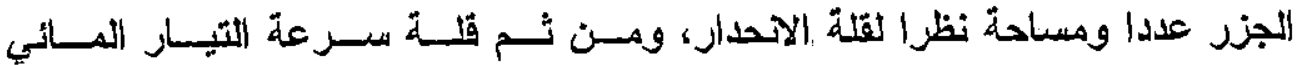
ومن هنا يميل النهز للإرباب، حيث نقل كفاوة المجــري ويــتخلص مسـن حمولتــه في شيكل حواجز أو جزر غاطسة.

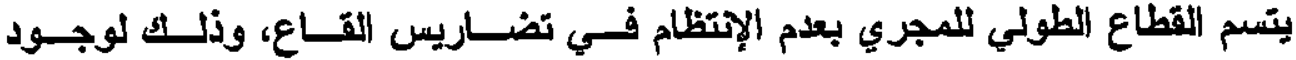

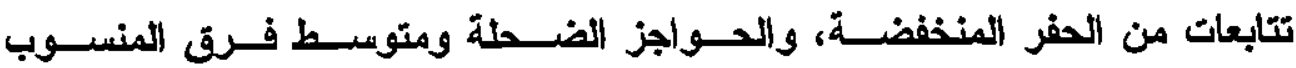
بينهما بصل V.ام، وينتج عن هذا حالة مسن عــدم الإســقرار نتيجــة لإتحـراف تيار التهر من جانب لأخر مما يؤدي إلي زيـــادة تعــرج المجـري، وهــو الســبب الأساسي الأذي يؤدي إلي تكوين المنعطفات النهرية وزيادة تعرجها.

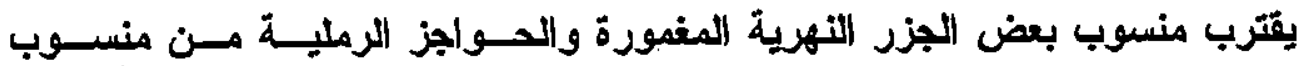

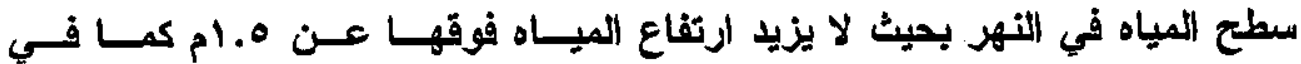

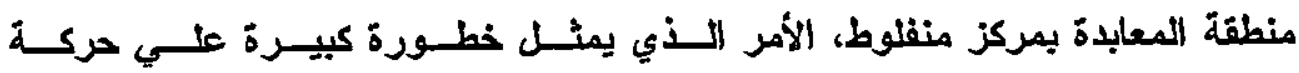

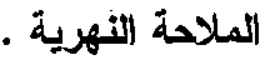

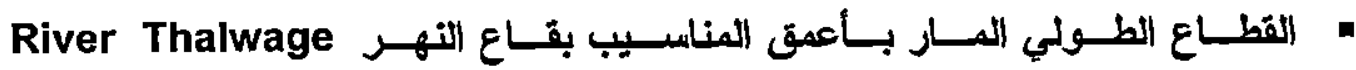

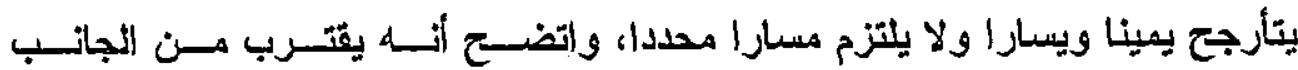

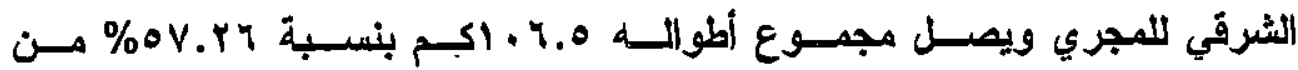

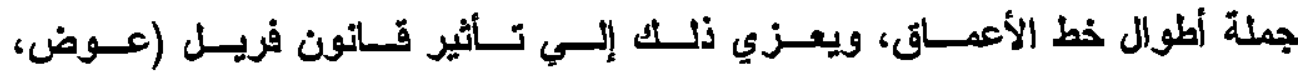

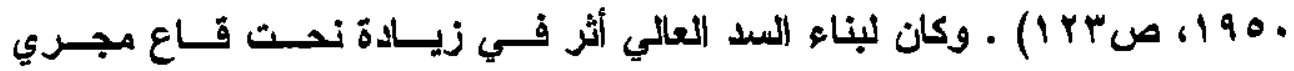
نهر النيل في مصر وزيادة عمقه بشكل عام علي طول مجري نهز النيل كله. 
جيومدوفولوجية النحت والترسيب في ضفاف مجرى النيل

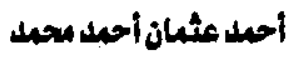

\section{بمحانظة أسيوط}

$=\frac{\mathrm{V} T}{\mathrm{G}}$

تختلف البحيرات المائية في خصائصــها عـنـ القنــوات المائيــة المهجهـورة

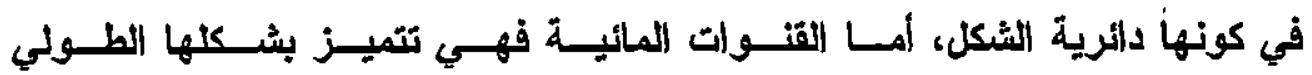

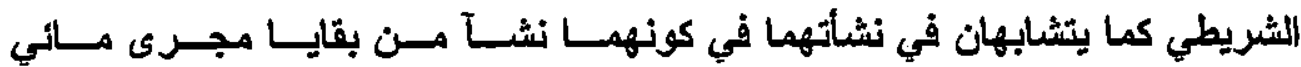

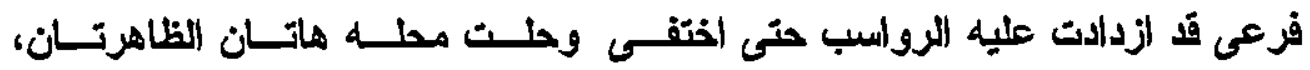
ويمكن أن نطلق عليها البحيرات المتبقية تجاوزا لبقائهــا على قائمسـة مــن بقايــا

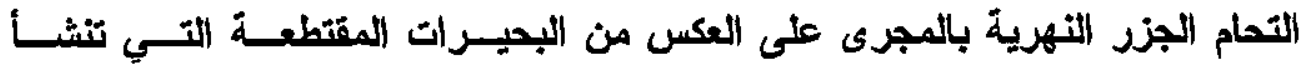

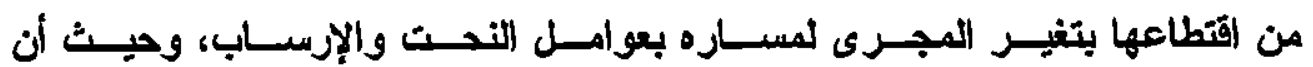

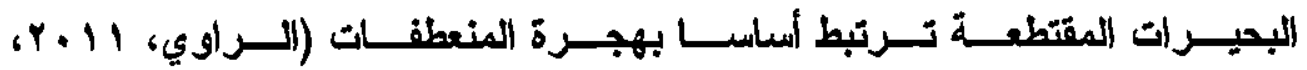

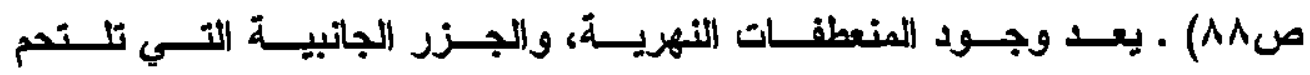

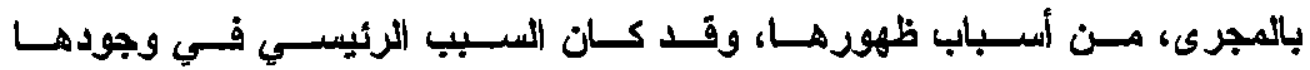

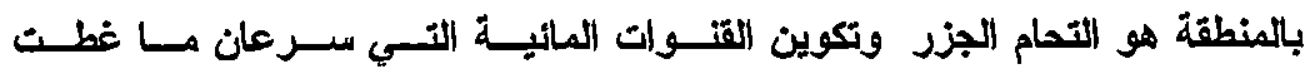

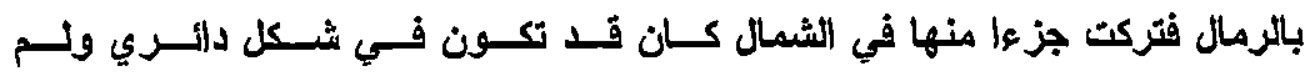
تستطع عوامل الردم والإرساب تسويتها وإلحاقها. بمستوى بالسهل الفيضي.

\section{Back Swamps اللينيخات الخلفية}

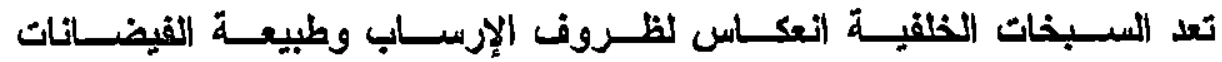
واختلافت مناسيبها من عام لآخر، وهى عبــارة عـن منخفضــات ضسطة صــيرة

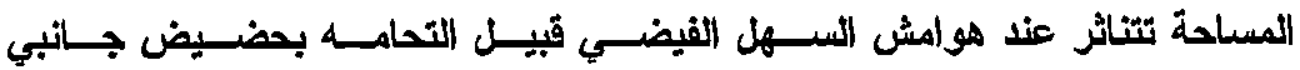

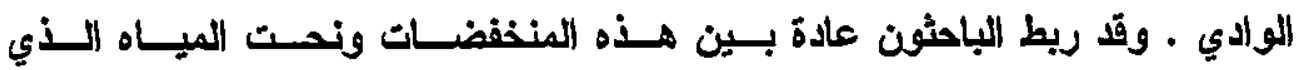

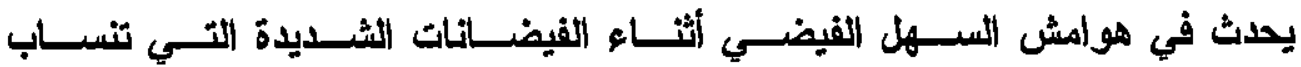




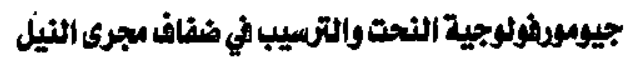

أجمد عثمان أحسد منعد

\section{بسحانظة أسيوط}

$=\frac{\mathrm{C} T}{\mathrm{C}}$

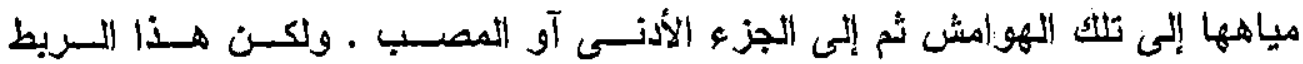

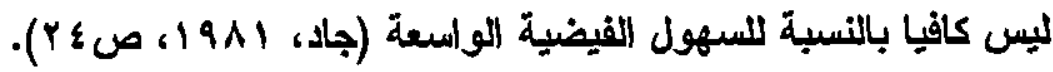

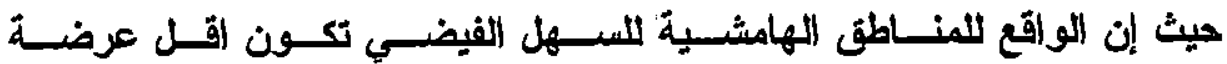

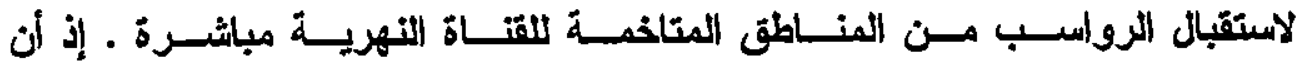

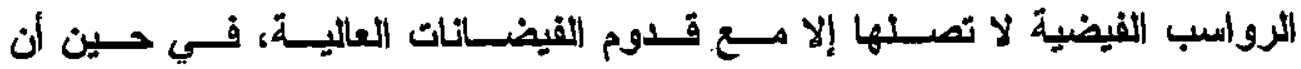

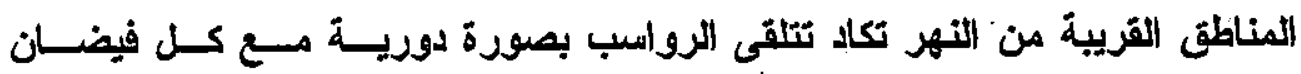

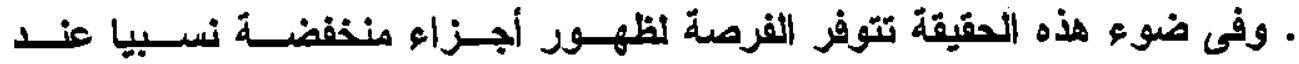

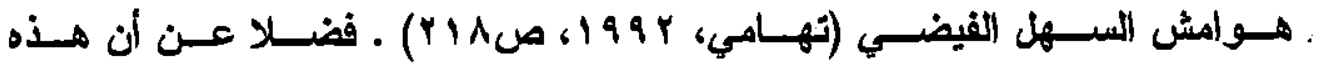

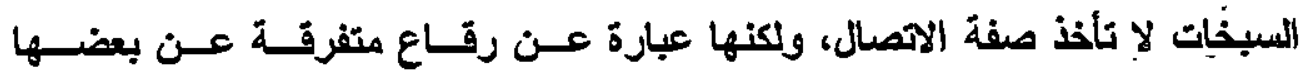

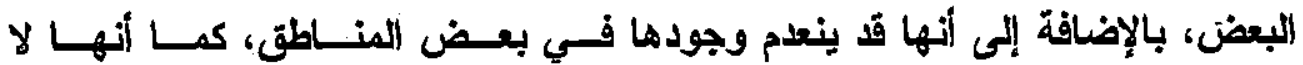
تأخذ شكل المجارى الضحلة التي تصرف المياه بالمعنى المفهوم. ولقد كانت هذه السبخات الخلفية تستمد مياهها من عدة مصادر أهمها :

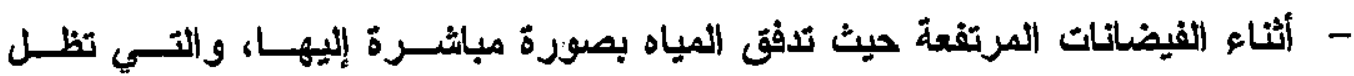
متبقية فيها دون انصراف، نتيجة لانخفاضسها النسـبتي عسن منسـوب الأراضسي إلمجاورة، بالإضاقة إلى آن تريتها تتكون من رواسب دقيةــة العجسم تجعـل مسن الصعوبة تسرب المياه لأسفل. - التسرب الجاتبي لمياه الفيضانات المتوسطة و المنخفضة. - مياه الصرف التي يقوم بصرفها السكان من المزارعين إلبها. 
$=$ VT

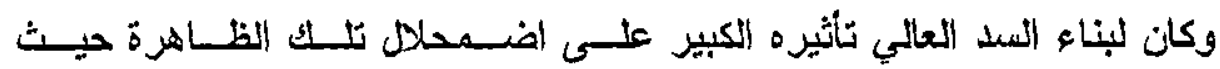

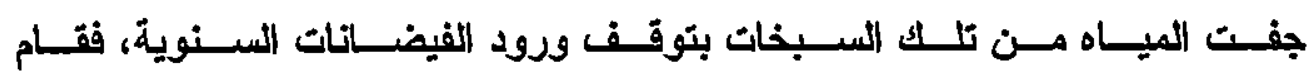

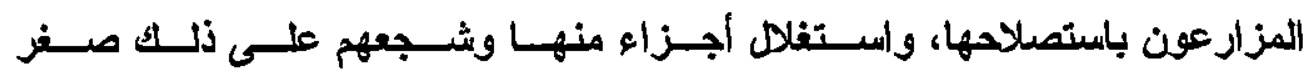

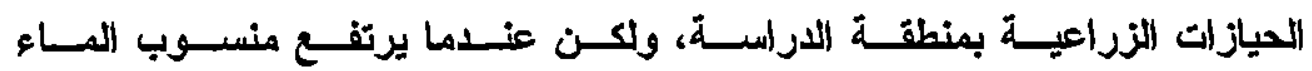
الباطني فأنه ينجذب إلى السطع بفعـل الخاصـية الثــرية، حيـث تتبخــر الميــاه

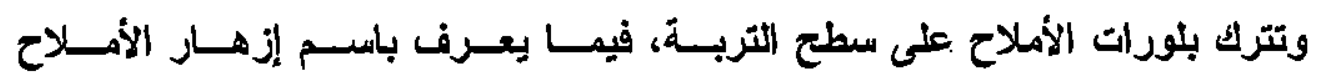

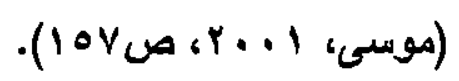

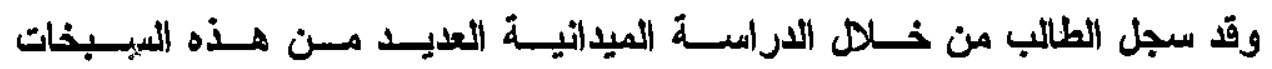

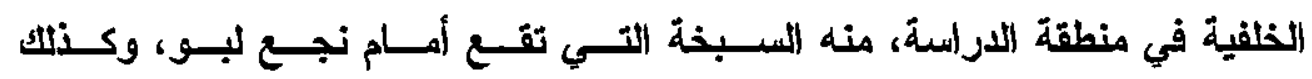

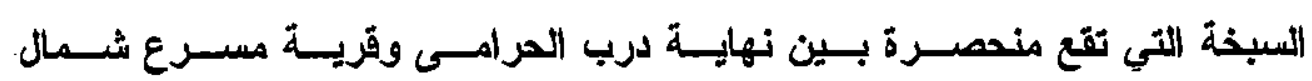
غرب أسيوط. يعالج البحث جيومورفولوجية النحت والترسيب فـي ضـفاف مجسرى التيـل فــي منطقة الار اسدة من خلا دراسة الآتي:

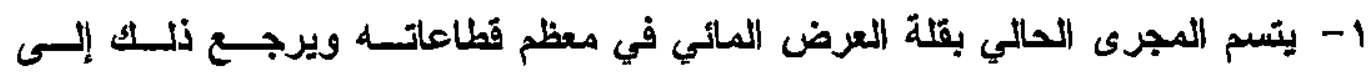

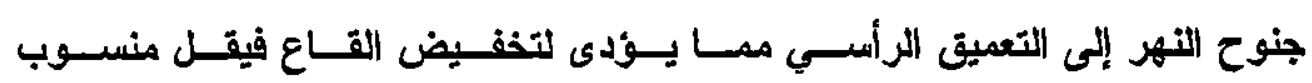
المياه ويالتالمي يقل اتساع المجرى.

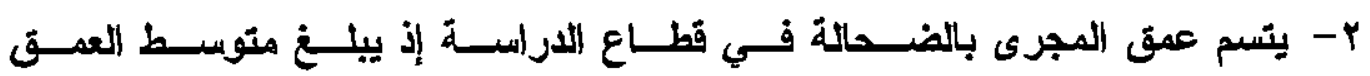

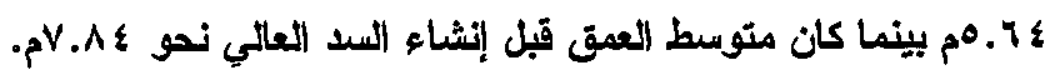


جيومواشولوجية النحت والترسيب في ضفاف مجرى النيل

أحمد عثمان أحسد محعد

\section{بعا:ita أسيرط}

$=\mathrm{V \varepsilon}$

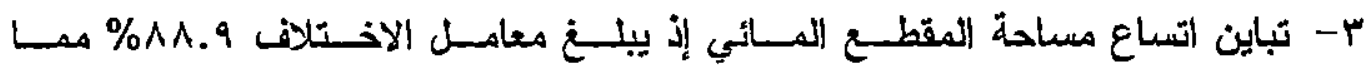

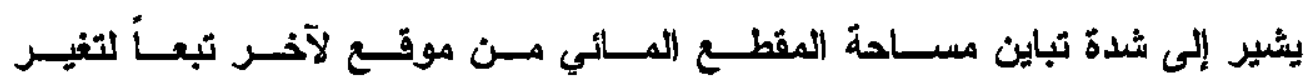
الخصائص الوهيدرولوجية للمجرى، ومدى تأثيرها فـي عمليـة التحــت والاتهيـال للضفاف.

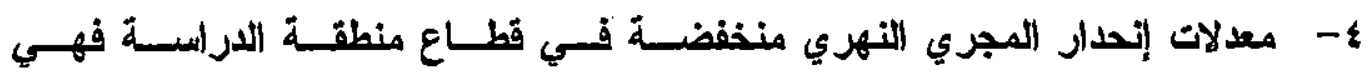

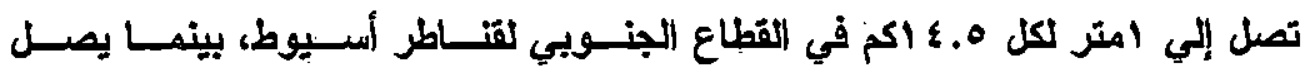

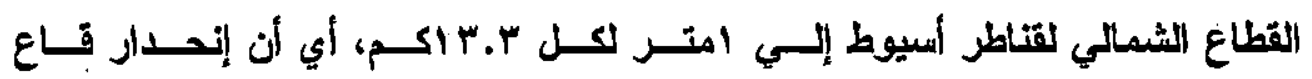

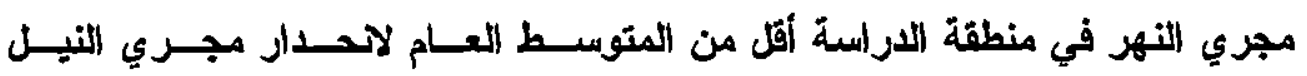

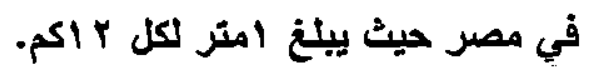
هـ - يتأرجح خط سير أعمق المناسيب بقاع النهر يمينـأ ويســارأ ولا يلتـزم مســارا محدגi.

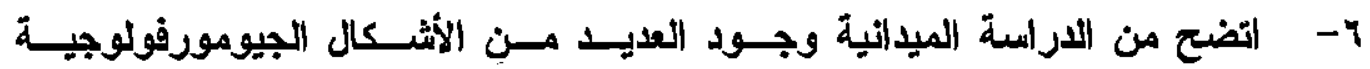

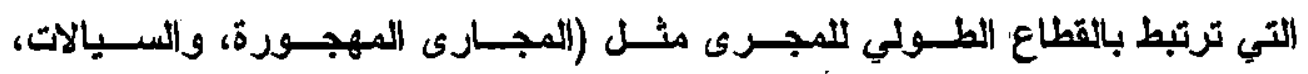
والحواجز الرملية، والمنعطفات (النهرية، والجزر النهرية).

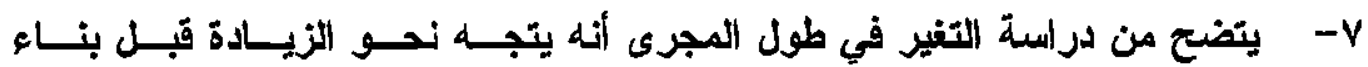

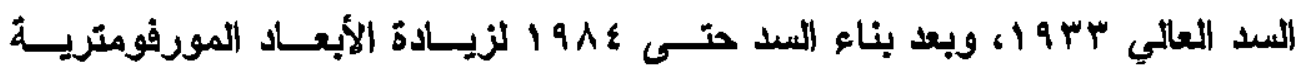

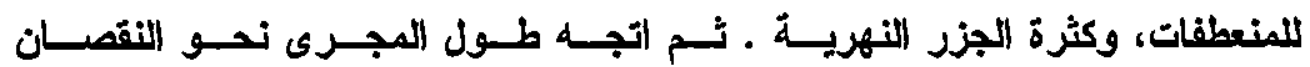
واستمر حتى الآن لآضمام العديد من الجزر إلى السهل القيضمي. 


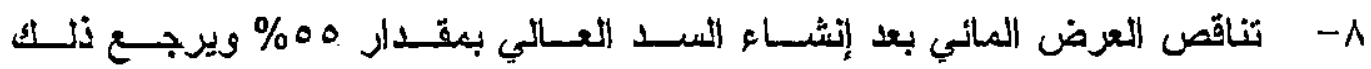
لالضمام الجزر إلى السهل الافيضــي بعـد أن انخفـض منســوب الميــاه وتحسـول بعض المجارى إلمى مجارى مهجورة .

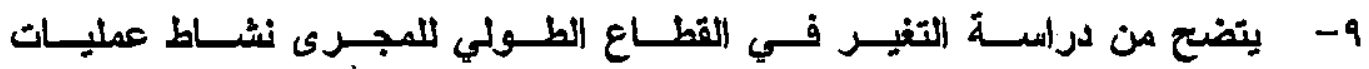

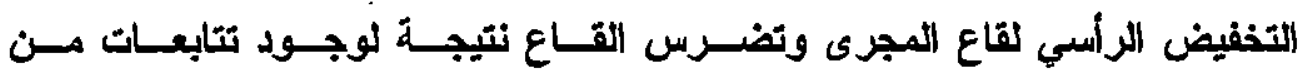
الحفر والحواجز الضحلة تعبر عن نشاط عمليات النحت الرأسي.

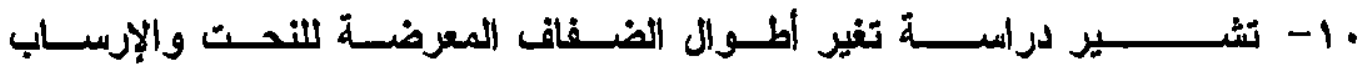
إلى وجود نوع من التوازن الايناميكي بين قــوى النــــت والإرســاب قبـل إنشــاء

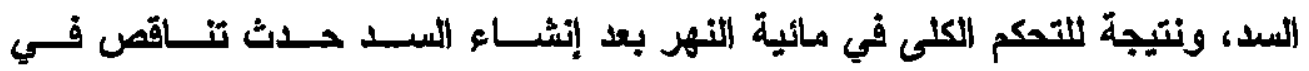

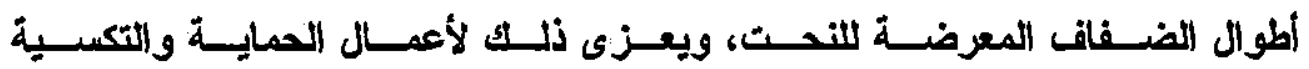
الحجرية التي أسهوت في تهذيب المجرى. 1 - اليتبادل التوزيع المكاني بين مواضع النحت والإرساب قبـلـل إنشــاء الســد الأمسـر

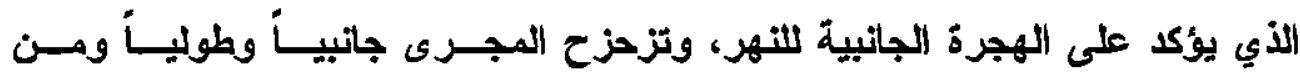
ثُ حافظ التهر على أتساع مجراه ومساحة مقطعه المائي.

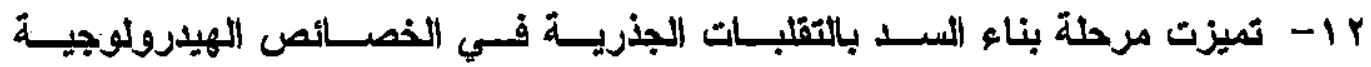
للتهز بعد احتجاز كميات هائلة من الرواسبب، وانخفاض التصريف المائي.

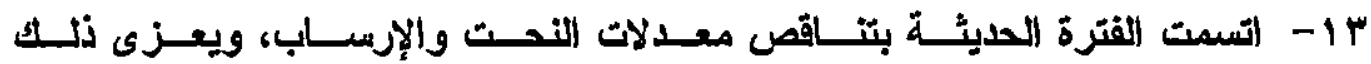
لوسائل حماية جواتب الضفاف من النحت والاتهيال. 
جيومورفولوجية النحت والترسيب في ضفاف مجرى النيل

أحمد مثعان أحعل محعل

\section{بمحافظطة أسيرط}

$=\frac{\mathrm{C}}{\mathrm{C}}$

W أولأن- المراجع المربينة:

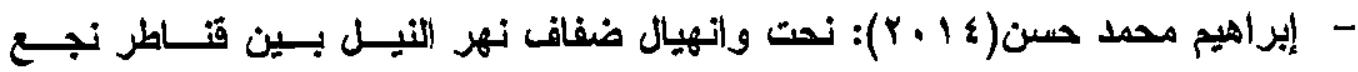

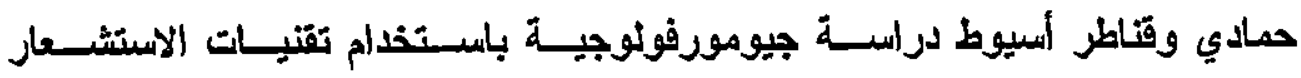

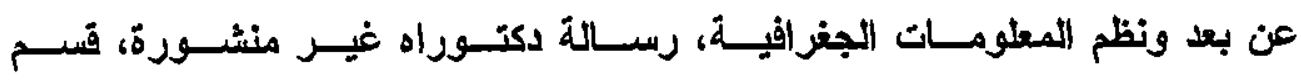
الجغراقيا، كلية الآداب، جامعة الإسكندرية.

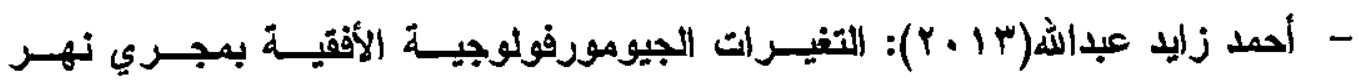
النيل بمحافظة أسيوط باستخدام تقنيات الاسنثــعار عـن بعـد ونظــم المعلومــات الجغرافية، المجلة العلمية، كلية الآداب، جامعة أسيوط.

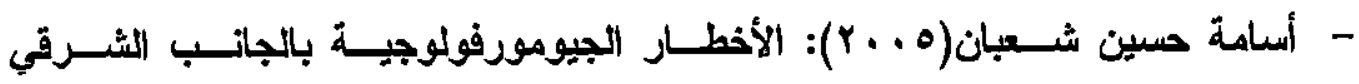
لوادي النيل بمحافظة سوهاج "دراسة فــي الجيومورفولوجيــا التطبيقيـةة"، رســالة دكتوراه غير منشبورة، قسم الجغرافيا، كلية الآداب، جامعة المنيا.

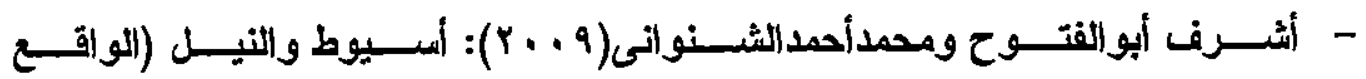
والتطور)، قطاع خدمة المجتمع وتنمية (لبيئة، جامعة أسبوط.

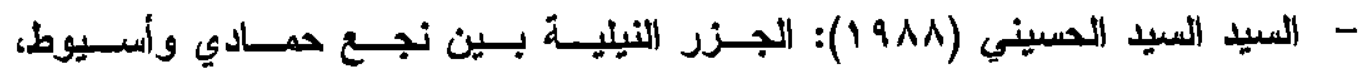

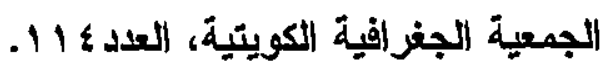
- السيد السيد الحسيني (1991): نهــر التيـل فـــي مصــر منصنياتــه وجـزره دراسة جيومورفولوجية، مركز إنشر جامعة القاهرة. 


\section{بمحانظة أسيوط}

$=\frac{\mathrm{VV}}{\mathrm{O}}$

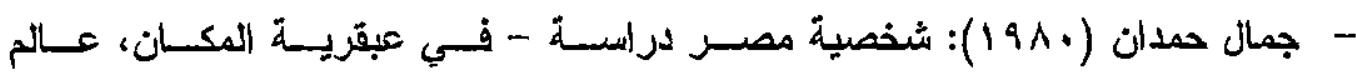

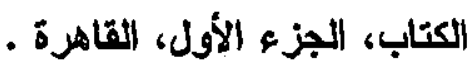

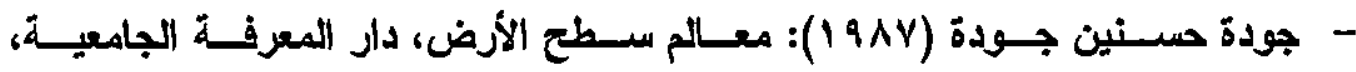

الإسكندرية.

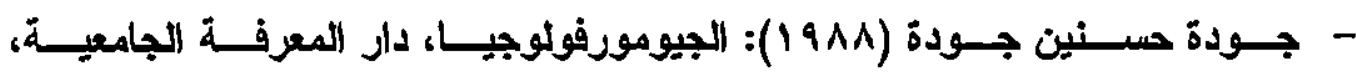
الإسكندرية.

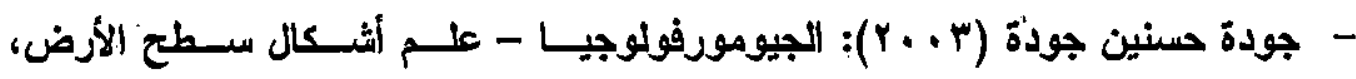
مع تطبيق بأبحاث في جيومورفولوجيــا العـالم العربــي، دار المعرفــة الجامعبـة، الإسكندرية.

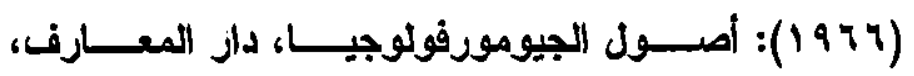

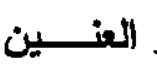
الإسكندرية.

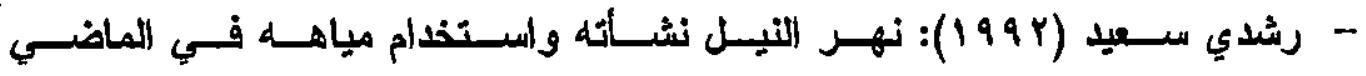
والمستقبل، دار الهلال،، القاهرة.

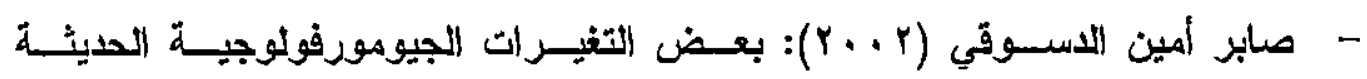
لمجري نهر النيل بين المنيا وينــي ســويف، المجلــة الجغرافيــة العربيــة، العــد و ب، الجزء الأول، القاهزة.

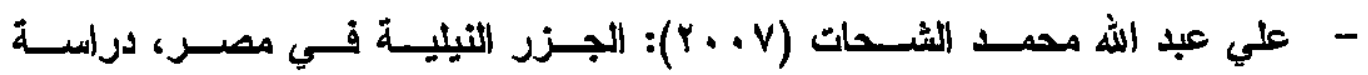
جيومورفولوجية، رسالة دكتـوراه غيـر منشسورة، كليـة الآداب، جامعسـة عـين شمسن. 
جيوسونوالمجية النحت وإترسيب في ضفاف مجرى النيل

أحسل مثعان أحسد محعد

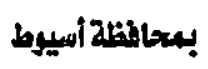

$=\mathrm{VA}$

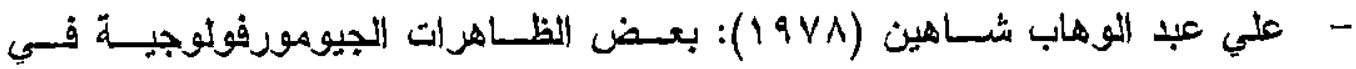
دلتا الثيل، المجلة الجغرافية العربية، العدد ال ا، القاهرة.

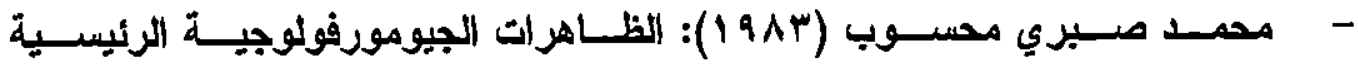
دراسة تطليلية بالأشكال والرسوم التوضيحية، مطبعة الإسر اءو، القاهرة.

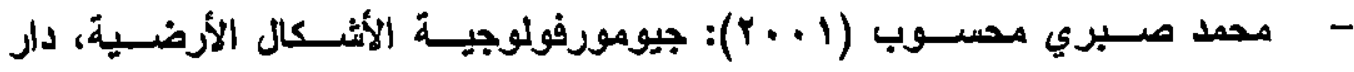
الفكر العربي، القاهرة.

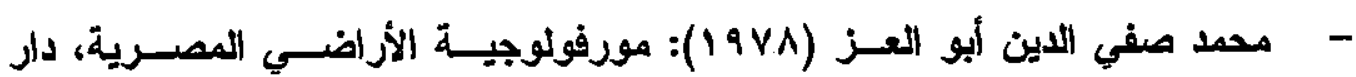
الأنهضة المريبة، القاهرة.

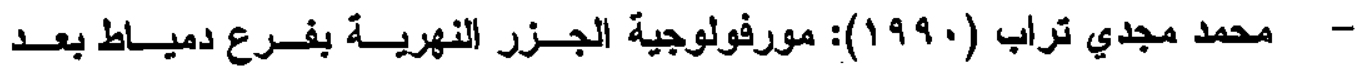
بناء المد العالي، المجلة الجغرافية العربية، العدد r r القاهرة. - محمد عوض محمد (1900): نهــر النيـلـ الهيئــة المصــرية العامــة للكتــاب، مكتبة الأسرة.

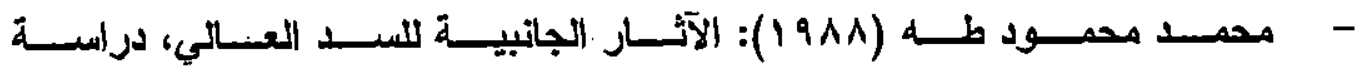

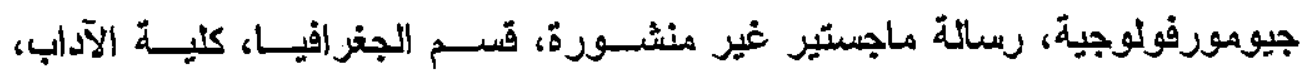
جامعة عين شمس. - مدوح تهامي عبد الحي عقل (Y99r): وادي اللنيـل بـين سـوهاج وأسـيوط،

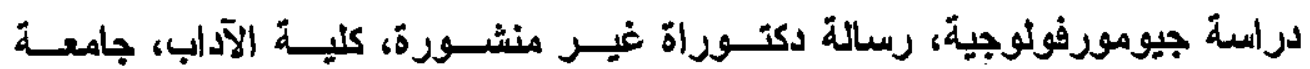
الإسكندرية. 
جيوسونافولوجية النحث والترسيب في ضفاف سجرى النيل

أحسل عثمان أحمل مسحد

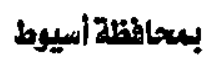

$=$ V9.

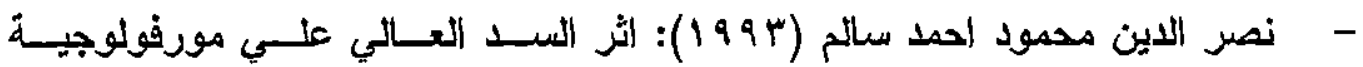
مجري النيل فيما بــين خـزان أســوان وقنساطر إبــنا، رســالة ماجسـتير غيــر منشورة، كلية الآدلب، جامعة الإسكندرية.

ثانيا : المراجع الأجنبية :

1- Ashour, M. M., 1993, Recent changes in The Nile channel, Bull. Soc. Geo. D, Egypt. Vol. 66, pp. 113-133.

2- Attia . M. I., 1957, Deposits in The Valley and Delta Cairo . Gover. press .

3- Ball, J. 1939, Contribution to Geography of Egypt. Survey of Egypt, Cairo.

4- El - Husseini, S.S. ( 1974a): On Recent Nile Aggragation, Journal of Cairo University in Khartoum Vol: 5 PP.113. 5- El - Husseini, S.S. ( 1974b): channel pattern of The Nile in Lower Egypt. Bull. Soc. Geo. D, Egypt. Vol. 47, pp. 129-152. 


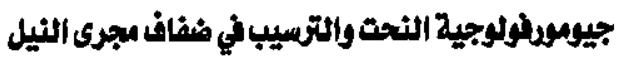

أحسل عثمان أحسد مسعد

بعانظة أسيرط

$\Lambda$.

6- Hurst . H . E., 1652. The Nile A General Account of The River and The Utilization of lts Waters, Constable London . 7- Hurst. H. Black and Simaika, 1961, the Nile Basin, 6 th supplement to vol.9, ministry of public works Egypt, Cairo. 8- Leopold, L. B.,Wolman.m.G.\&Miller.j.p,1964,fluvial processes in Geomorphology freeman, London. 9- Simaika. Y., 1940, the suspended matter in the Nile physical Dept. paper No, 40, cairo. 